\title{
Analysis of the pattern of energy consumptions and its impact on urban environmental sustainability in Jordan: Amman City as a case study
}

\author{
Rami Nabil Dar-Mousa* (1) and Zeyad Makhamreh ${ }^{*}$
}

\begin{abstract}
Background: The energy sector plays an important role in the economic growth in Jordan due to the fact that Jordan imports around $97 \%$ of its needs from primary energy. The purpose of this study is to explore the pattern of electricity consumption and energy loss to highlight the strengths and weakness of energy efficiency in the context of the urban sustainability of Amman City in Jordan.

Methods: The design of sustainable urban development is based on the urban interdependencies approach, which incorporates the stakeholders to identify and pursue synergies between multiple sectors. This approach includes the identification of the functional sectors, which are related to institutional and behavioral levels in the society, raising the level of institutional performance and improving the quality of urban services. The spatial statistical analysis approach and GIS applied to analyze the consumption pattern of electrical power in the study area.

Results and conclusion: There was a considerable increase in the peak domestic consumption, as the peak load reached 3320 MW in 2017 with an annual increment rate of 4.9\%. Regarding energy efficiency, the value of total electrical energy losses reached $13 \%$ in 2017; around $90 \%$ of this loss occurred in the electrical distribution stage. Geographical distribution of the household electrical power shows that the east and middle parts of Amman have low consumption levels compared to the west residential parts. The energy consumption pattern has an inverse relation with the population distribution, family size, and building characteristics in the city. This is clearly identified by addressing the downtown region that has the lowest energy consumption and the highest-density population, while the western part has the highest energy consumption and low-population density. These variations can be referred to as differences in social and economic behaviors of inhabitants in both high-density and low-density population areas.

This analysis reflects the influence of several factors that should be taken into account in energy sustainability strategies. Energy consumption is influenced by the characteristics of households which include building size, household income, total energy cost, and building characteristics (e.g., building design, age, location, and using thermal insulation system for buildings).
\end{abstract}

Keywords: Energy consumption, Sustainability, Amman, Urban pattern, GIS

\footnotetext{
* Correspondence: Rami.Musa1983@gmail.com; z.makhamreh@ju.edu.jo

Department of Geography, University of Jordan, P.O. BOX:11942, Amman

13926, Jordan
}

(c) The Author(s). 2019 Open Access This article is distributed under the terms of the Creative Commons Attribution 4.0 International License (http://creativecommons.org/licenses/by/4.0/) which permits unrestricted use, distribution, and reproduction in any medium, provided you give appropriate credit to the original author(s) and the source, provide a link to the Creative Commons license, and indicate if changes were made. 


\section{Background}

The energy consumptions pattern and its sustainability influence the urban agglomerations and population growth in cities [1]. There are many studies and literature, which address the ways of sustainability and energy efficiency in cities and urban environments. The development of economic, social and environmental sectors is the tackle point to achieve effective sustainability in an urban environment "triple bottom line" [2]. Modern cities become a target for the urban population due to the effectiveness in providing resources for all kinds of services (e.g., water, food, energy) in order to meet the livelihood requirements [3]. The metabolism theory considers the cities like a living organism, which can be represented by different growth stages in their life cycle such as childhood, youth, maturity, aging, disease, or renewing youth [4]. According to this theory, the city needs resources and energy for implementation of the metabolism energy flows [5].

The current projections indicate that more than 66\% of the world's population will live in cities by 2050, while in Jordan the urban population compromises more than $80 \%$ of the total population [6], and greater Amman municipality includes more than $43 \%$ of population within its borders. On the other hand, the urban buildings and agglomerations that based on sustainable effective planning can help in founding the modern cities, which provide high comfort to the population services and energy efficiency standards [7]. Applying this concept in Amman City, the focus is not limited only to the quantity and quality of these services but shall consider the adopted methodology to deal with its operations within the urban environment, the pattern of energy consumption, and the driving forces of consumption of resources. The energy consumption pattern is an essential part of the city services and becomes a metabolic theory in urban areas, which constitute a reference framework in integrated urban energy systems. The residential requirements account for about $36 \%$ of the total electricity consumption amount of Amman [8], according to this figure, adopting practical efficient energy reduction strategies could reduce the related costs of energy consumption.

Since 2011, the instability in Middle East region and fluctuations of the oil global market have strongly affected the fossil energy consumption such as oil and natural gas, this can be addressed by some economic consequences which are reflected by the oil price instability. Taking into consideration, the political consequences of the unstable neighboring countries to Jordan, these conditions besides the environmental factors stress the need for shifting towards sustainable energy resources in Jordan. Investigating the pattern of energy consumption is a crucial issue to determine the priorities of the transformation process, which shall lead to take an action towards sustainable urban consumption in the energy sector in Jordan. Therefore, the main objective of this study is to analyze and identify the pattern of energy efficiency and electrical energy consumption in Jordan taking Amman City as a case study.

\section{Methods}

The design of sustainable urban development is based on the NEXUS urban interdependencies approach, which incorporates the stakeholders to identify and pursue synergies between multiple sectors. This approach includes the identification of the functional sectors, which are related to institutional and behavioral levels in the society, raising the level of institutional performance and improving the service quality. The ultimate goal of urban NEXUS approach is speeding up access to services, increase the quality of service and the quality of life [9]. The mutual interest approach interlinkages between environmental resources and transformations and flows across spatial scales and independent parts, rather than merely on individual components, where management of complex systems is taking into account [10].

Jordan is located in the Eastern Mediterranean region with an area of about $89,300 \mathrm{~km}^{2}$. The main population is concentrated predominantly along the mountains' regions with the main cities: Irbid, Zarqa, Amman, Salt, Madaba, and Karak. Amman is the capital city whose population percentage reaches about $43 \%$ of Jordan population in 2018. Figure 1 shows the location of Amman City in Jordan. The study focuses on Amman City and its surrounding suburbs with an area of around $900 \mathrm{~km}^{2}$ that is part of the greater Amman area. Amman represents the main economic center of the country, with over $85 \%$ of the total industrial and service activities, which are located in the capital city together with the industrial suburbs and peri-urban zone towards Zarqa City [11].

The study curriculum is based on the description and analysis of energy efficiency performance in Amman City (study area). knowing the pattern of consumption can work to determine priorities in the process of taking decisions on sustainable urban environment for the energy sector in Amman, as the key to improving energy efficiency lies in better understanding of patterns of consumption [12].

To show the spatial autocorrelation pattern of electricity consumption in the study area, the spatial statistical analysis techniques in GIS were applied [13] on the Life-Cycle Assessment (LCA) as a tool, that can help to understand the various environmental benefits and results [14]. The purpose of LCA is to build a comprehensive environmental characterization of the outputs, and this easily can be applicable to the GIS techniques. Noting that LCA was not the core topic to be investigated 


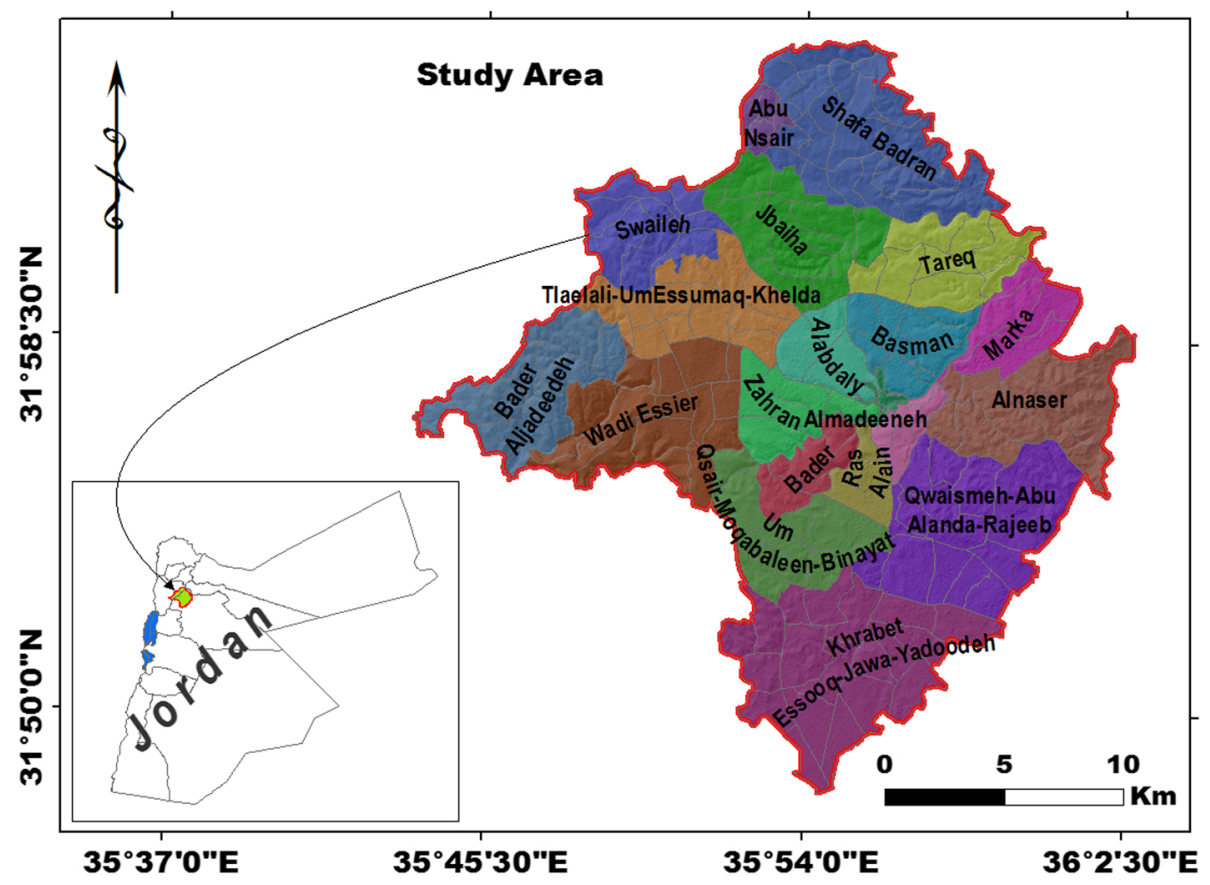

Fig. 1 Location map of Amman City in Jordan

or followed during this research; however, its coupling the GIS was the key benefit to follow, by using the spatial statistical analysis techniques related to the study variables. Also, GIS offers the opportunity to manage and automatically process information at larger scales taking into account the spatial dimension and achieving a higher level of detail. GIS capacity to tackle huge spatial databases may support LCA at the territorial scale and reduce the working time to perform the LCA studies in the future [15].

GIS was applied through the ArcMap info version 10.5, represent maps on the study factors, and calculate its key values in order to follow the requirements of the Global Moran's Index. Moran's $I$ is a measure of global spatial autocorrelation, which indicates whether there is an autocorrelation among all spatial features. The domain of Moran's $I$ is from -1 (perfect dispersion) to 1 (perfect clustered). Random spatial distribution is indicated when Moran's $I$ is 0 . In other means, the larger Moran's $I$ is, the more clustered the spatial features are [16]. Test of the spatial autocorrelation (Global Moran's $I$ was based on both feature locations and feature values simultaneously. It is used to evaluate types of pattern distribution, Moran's $I$ index is calculated using the equation below.

$$
\text { Moran's } I=\frac{N}{\sum_{i} \sum_{j} w i j} \frac{\sum_{i} \sum_{j} w i j(X i-\bar{X})(X j-\bar{X})}{\sum_{i}(X i-\bar{X})^{2}}
$$

where $N$ is the total number of observations (points or polygons) $i$ and $j$ represent different locations; $\mathrm{Xi}$ and $\mathrm{Xj}$ are values of the variable in the $i$ th and $j$ th locations, and $\bar{X}$ is the mean of the variable $X ; W i j$ is a measure of spatial proximity for pairs $i$ and $j$ [17].

Figure 2 shows the spatial autocorrelation pattern for per capita electricity consumption, using Global Moran's $I$ in Amman City. The $z$ score and $p$ value are used to evaluate the significance of that Index. $p$ values are numerical approximations of the area under the curve for a known distribution. This analysis returns a $z$ score of 13.46 associated with a zero $p$ values which indicates it is unlikely that the observed spatial pattern reflects the theoretical random pattern. All Moran's $I$ values are measured based on electricity consumption in the study area in 2015. The figure present graphics and numeric results for Moran's $I$, three patterns are depicted: dispersed, random, and clustered. These patterns represent per capita electricity consumption in Amman City. The clustered pattern suggests a strong spatial autocorrelation in which Moran's $I$ is equal to 0.6. Which implies that domestic electricity consumption, representing the key factor in the study area, and given the value 0.6 ; the nearby locations tend to have similar values and positive autocorrelation as shown in Fig. 2.

\section{Results and discussion}

\section{Current state of energy sector in Jordan}

Energy management is a big challenge for Jordanian economy due to the paucity of local energy resources and relying on imported energy sources. The energy 


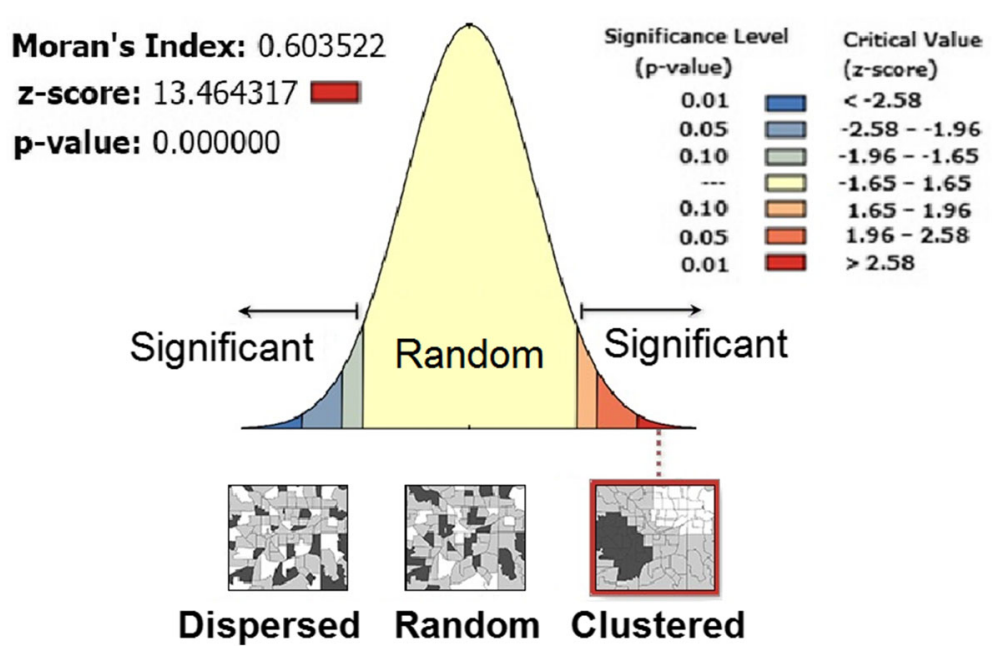

Fig. 2 Spatial autocorrelation pattern for per capita electricity consumption, using global Moran's /

demand of tons of oil equivalent is growing by percentages of $6.4 \%$ annually. In 2016 , the electricity sector contributed with more than $41 \%$ of the total energy consumption [18] and with an annual growth rate reached to $2.8 \%$ with 3.7 million tons of equivalent oil consumption in 2016 compared to 3.6 million tons of equivalent oil in 2015 [19].

Regarding the electricity consumption in the main regions of Jordan, Table 1 clarifies the electricity consumption by three distribution companies. The consumption of Jordan Electricity Power Company (JEPCO) which supplies electricity to Amman, Zarqa, Madaba, and Salt cities, contributed more than $60 \%$ of the total consumption rate of the three distribution companies in 2016.

Taking into consideration the instability of the energy market, the energy security in Jordan testifies swings and sometimes shocks [22]. The primary energy consumption in Jordan reached 9.5 million tons of equivalent oil in 2016. The quantity of the fuels consumed for the purpose of power generation in 2016 totaled around 3.4 million tons of natural gas, 0.3 million tons of heavy fuel oil and 0.013 million tons of diesel, the total fuel

Table 1 The electricity consumption by the three distribution companies in GW/h $[20,21]$

\begin{tabular}{lllllll}
\hline & 2011 & 2012 & 2013 & 2014 & 2015 & 2016 \\
\hline EDCO $^{1}$ & 2363 & 2492 & 2612 & 2777 & 2924 & 3461 \\
JEPCO $^{2}$ & 8008 & 8473 & 8511 & 8759 & 9210 & 10,975 \\
IDECO $^{3}$ & 2138 & 2181 & 2306 & 2521 & 2723 & 3227 \\
Total & 12,509 & 13,146 & 13,429 & 14,057 & 14,857 & 17,663 \\
\hline
\end{tabular}

${ }^{1}$ Electricity Distribution Company (EDCO) covers the south and east areas in Jordan in addition to the Jordan Valley

${ }^{2}$ Jordan Electricity Power Company (JEPCO) covers the middle area in Jordan (Amman, Salt, Madaba, and Zarqa)

${ }^{3}$ Irbid District Electricity Company (IDECO) covers the north area in Jordan cost reached to around 790 million Jordanians Dinars. The electricity demand in Jordan depends on several factors, most importantly the below key factors:

- Environmental factor: It affects the electricity demand in relation to the variance in humidity and ambient temperature in different seasons during the year.

- Demographic factor: It relates the electricity demand with the population growth and life pattern, in addition to the increased numbers of refugees from neighborhoods countries.

- Energy tariff factor: This factor is a part of the energy policy, and it affects the electricity consumption pattern of small and large consumers.

Figure 3 represents the energy distribution by different sectors in Jordan in 2016. This figure shows that the transportation sector contributes to around $45 \%$ of total energy consumption [22, 23]. The household sector is the second most important sector that consumes energy with $23 \%$, mainly distributed between heating, cooling, lighting and other uses, while the industry sector comes at the third level with $21 \%$. In order to overcome the economic and environmental effects of this issue, the policymakers have to rebuild the energy strategy in Jordan. This should consider the renewable energy sources, oil shale retorting, and oil shale direct burning to generate electricity, in addition to promoting the use of the electric vehicles and public transport by developing transportation networks [24]. This orientation was translated actually on the ground through the adoption of the supporting policies to encourage the investment in renewable energy projects and public transportation, in addition to exempt the electric vehicles in order to reduce the dependency on imported fuels. 


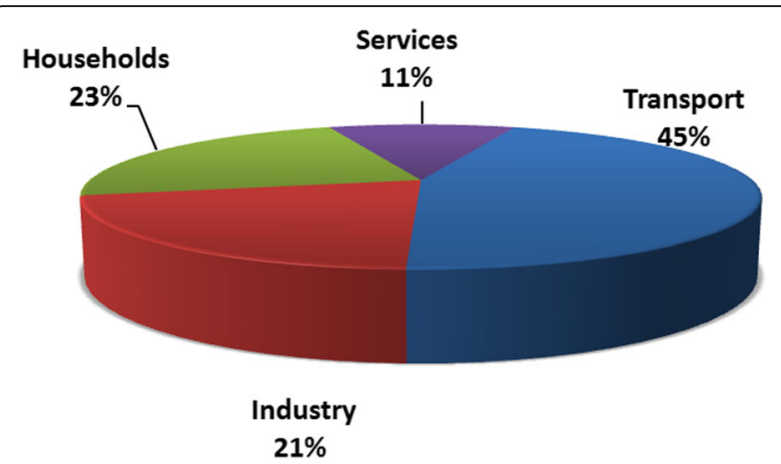

Fig. 3 Sectoral distribution of energy consumption in Jordan [22]

The main challenges of urban environments are creating innovative methods and ways to raise energy efficiency and improve user behavior [25]. Implementation of energy efficiency through advanced technologies or sustainable practices is extremely important. Many efforts have focused heavily on energy efficiency policy and technology, but that is not enough since the user practices and consumer behavior are some important factors in influencing the amount of energy consumed. Significant efforts were made to increase energy efficiency and reduce the carbon emission of energy consumption, in this regard, the transport system has received high attention in order to improve the efficiency and reduce the congestion, pollutants, and environmental degradation [26]. Existing challenges in urban environments is based on using innovative methods and creative ways to raise energy efficiency and improve user behavior [13], and these methods known as retrofitting or reformatting of existing housing and restructured the buildings to make them more efficient in energy consumption process to be increased as adviced by LCA that ultimately will be increased. In order to reduce Amman City energy consumption, a range of effective properties of carbon footprint reduction should be activated [27], such as thermal insulation process, specific height and size, and appropriate location's direction of houses in confronting the sunlight [28], in addition to the nature of the material used in the construction process to be environment friendly. In this context, the role of social learning and public awareness of the community towards efficient use and consumption behavior become very important [28]. Energy efficiency associated with shifting towards alternative renewable energy and prioritization is a complex and overlapping process. Therefore, it is important to improve the energy efficiency consumptions and develop a standard practice for better understanding of energy systems and identify appropriate paths for current and future energy policies [29].

Energy efficiency and rationalizing consumptions aims to improve the lift value and its ability to meet the basic needs of the user, with the most efficient methods and available means to get the maximum possible return, with the least possible amount of energy consumption, without affecting daily life and living conditions of users [30].The integration of energy efficiency with rational consumption is crucial to determine the optimal path of economic development and increase the productivity of the local economy. In addition to reducing the budget deficit and support the competitiveness of the national economy by improving energy efficiency in various economic activities, this will reduce the cost of producing goods and services in Jordan [31].

Table 2 shows the contrast between consumption rationalization and energy efficiency. Rationalization depends on human behavior and means the optimal use of energy that leads to gain the best benefits and results. Using lighting only in places that are occupied is an example of energy rationalization. Increasing the performance solar cells is an example of energy efficiency and solar cells harvest only $18 \%$ of the total amount of solar radiation and convert it to electricity; if these cells are developed to raise their efficiency up to $80 \%$, this leads to quadruple electricity generation. Energy efficiency is based totally on technological progress [32]. Clarifying the relationship between energy efficiency and rationalization is an important issue to achieve a higher level of sustainability because there is a big difference between conservation strategy for sustainability and increasing efficiency level. In this regard, the access to the marginal level to rationalize or reduce consumption has not demonstrated the presence for a limit for efficiency.

\section{Status of the electrical power in Jordan}

Investigation the consumption pattern in the electric energy sectors at regional and global level shows a clear trend of increasing energy consumption in most countries of the world from 1990 to 2017. Table 3 illustrates the consumption value of electricity in Jordan distributed by various sectors; it shows that there is an increase in the household consumption rate from 2010 to 2016, also there is a small incline in the industrial sector consumptions. However, the consumption rates indicate an increase in the rate of consumption for domestic and commercial sectors; therefore, the importance of the rational use of energy in the household sector becomes an important issue in the sustainability of energy strategy in Jordan [34].

The building system and construction design are responsible for an excessive amount of the consumed energy in urban environments and in many other areas. This attributed mainly to the climate effect, for its role in the electric energy guzzle in consumption and generation through the burning of fossil fuels [36]. Figure 4 shows the electrical power consumption and distribution 
Table 2 The contrast between the energy efficiency and rationalization [33]

\begin{tabular}{|c|c|}
\hline Energy efficiency & Rationalizing energy consumption \\
\hline $\begin{array}{l}\text { - Energy efficiency depends on the use of advanced technology to reduce energy } \\
\text { use, conserve the same much performance. } \\
\text { - Focus on the performance of equipment and machinery. } \\
\text { - Replace the traditional light bulbs with a more efficient (LED) as well as home } \\
\text { thermal insulation and the use of energy-saving appliances. }\end{array}$ & $\begin{array}{l}\text { - Rationalizing consumption depends on individual behavior, } \\
\text { which leads ultimately to reduce energy consumption. } \\
\text { - Focus on the performance of human behavior. } \\
\text { - Switch off the light when out of the room. }\end{array}$ \\
\hline
\end{tabular}

pattern in the domestic sector of Amman City, and it shows that about $50 \%$ of the energy used in heating and cooling, with other sectors as $17 \%$ for cooking, $15 \%$ for water heating, $15 \%$ for home appliance, and for the lighting sector which corresponds to about 4\% [33].

The annual consumption of electric power per capita in Jordan has reached around $991 \mathrm{~kg}$ oil equivalents with a $4.1 \%$ growth rate. Table 4 shows the electrical losses in the energy sector in Jordan. The total electricity consumption in Jordan reached $18 \mathrm{TW} / \mathrm{h}$ by 2017 , the lost value was about $2526 \mathrm{TW} / \mathrm{h}$, which is equal to $13 \%$ with a total cost of 17 million Jordanian dinars according to the average cost of consumption. There are three stages of electric energy losses: generation stage, transportation stage and distribution stage, the generation and transport losses are very low compared to the size of the losses during the stage of distribution [8].

The losses in the distribution stage are mainly due to technical causes, like the harmonics issue, which is generated and passes through the distribution network in case no harmonic filters are implemented. This and other technical issues can be solved by increasing the budget of maintaining the distribution networks. In addition to the technical causes of the losses, there is an additional factor for such losses which is related directly with the customer's bad behaviors and through the energy meters tampering, and this kind of causes can be mitigated by activating the rule of law.

The main issue is in the continual sparring between stakeholders and implementers of the fossil energy system and sustainable renewable energy system. The fossil energy system group seeks to focus on energy efficiency and conservation, due to the current high cost and ineffectiveness of renewable energy. Whereas the second group believes that the adoption of a renewable energy system is the only way that will lead to energy security in the stage of sustainability and getting rid of old sources. However, the issues become more complex in the case of increasing demand on energy, the rapidly increasing consumption rate of fossil energy leads to fast degradation of the planet, through its devastating effects on the environment [37]. Adding to this effect, the transitions change in climate properties, the impact of the concept of hidden cost on human life, for example, the global climate will increase the demand for the needed energy. The extreme weather situation leads to increasing demand for energy in the form of heating and cooling by using air conditioning in summer and winter, which consumes a high amount of electricity [38].

Table 3 Electrical energy consumption by sector type (GW.h) [33, 35]

\begin{tabular}{|c|c|c|c|c|c|c|}
\hline & $\begin{array}{l}\text { Domestic and government } \\
\text { buildings }\end{array}$ & Industrial & $\begin{array}{l}\text { Commercial and } \\
\text { hotels }\end{array}$ & $\begin{array}{l}\text { Agriculture and } \\
\text { water pumping }\end{array}$ & Street lighting & Total \\
\hline $\mathrm{EDCO}^{1}$ & 916 & 345 & 361 & 1350 & 80 & 3052 \\
\hline$J_{E P C O}^{2}$ & 4997.4 & 2002.7 & 1700.4 & 576.3 & 170.1 & 9446.9 \\
\hline IDECO $^{3}$ & 1601.2 & 251.3 & 280 & 625.2 & 128.2 & 2885.9 \\
\hline Industrial companies & - & 1384.3 & - & - & - & 1384.3 \\
\hline Other companies & - & - & 74.3 & - & - & 74.3 \\
\hline 2016 & 7514.6 & 3983.3 & 2415.7 & 2551.5 & 378.3 & $16,843.4$ \\
\hline 2015 & 7227.6 & 3823.2 & 2376 & 2412.1 & 338.7 & $16,177.6$ \\
\hline 2014 & 6583.4 & 3878.3 & 2357.7 & 2284.2 & 315.6 & $15,419.2$ \\
\hline 2013 & 6265.4 & 3517.1 & 2414.9 & 2076 & 291 & $14,564.4$ \\
\hline 2012 & 6126 & 3464 & 2427 & 1955 & 305 & 14,277 \\
\hline 2011 & 5667 & 3486 & 2173 & 1899 & 310 & 13,535 \\
\hline 2010 & 5225 & 3262 & 2187 & 1868 & 315 & 12,857 \\
\hline
\end{tabular}

${ }^{1}$ Electricity Distribution Company (EDCO) covers the south and east areas in Jordan in addition to the Jordan Valley

${ }^{2}$ Jordan Electricity Power Company (JEPCO) covers the middle area in Jordan (Amman, Salt, Madaba, and Zarqa cities)

${ }^{3}$ Irbid District Electricity Company (IDECO) covers the north area in Jordan 


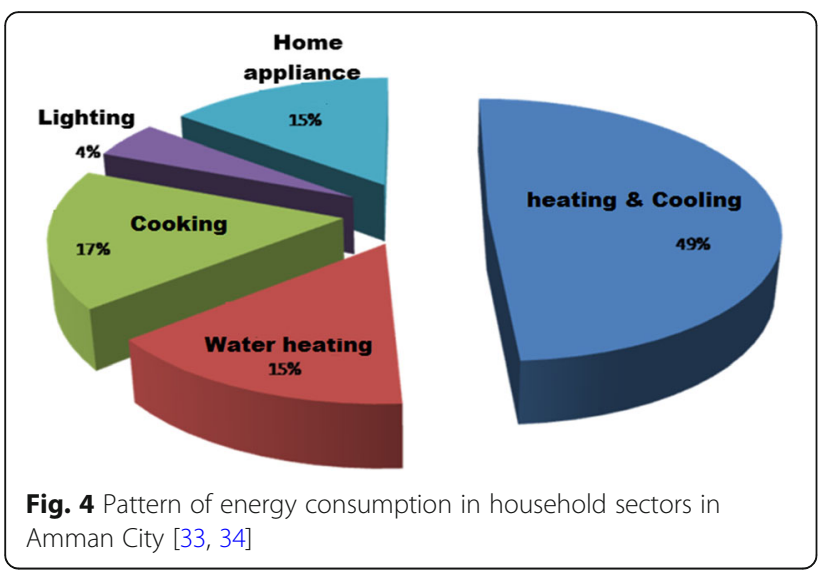

Pattern of electricity consumption in Amman City

The building type influences the energy consumption pattern. According to the USA energy research, like (lee's study in 2009) titled "The Influence of Urban Form on GHG Emissions in the U.S. Household Sector," multi-family building with more than five family's apartments use nearly $40 \%$ of electric power less than building with single families [39]. On the other hand, single families that live in a separate villa or independent house in the Australian city of Sydney consume electric power rates by $73 \%$ more than multi-family houses [40]. The residential buildings with a single family in Amman reach about $40 \%$ of the total number of buildings in the city and are almost located in the western part of the city. The total consumption volume in Amman for 2015 is estimated at about $4.2 \mathrm{TW} / \mathrm{h}$ with annual per capita $1087 \mathrm{~kW} /$ $\mathrm{h}$; these values are monitored through the Jordanian electricity company revenue section [41].

The consumption rate in summer season tends to use more fossil resources because it is characterized by long night with non-sleeping hours given the culture of summer activities for households, high temperature, and the extra incoming tourism and visitors' activities in the city, this affect the ecological footprint represented by the amount of solid waste production [42]. The waste production as an additional indicator proved the above, it shows an increase of $30 \%$ on average, except for transition seasons between summer and winter. Thus, the demand for electrical energy in winter season increases by $17 \%$ in all sectors in Amman City, due to the cold temperatures, with slight rising in demands for the residential sector by over than $40 \%$ compared to the other sectors.

From a geographical point of view, examining the spatial distribution pattern of the consumption rate of electrical energy in the city of Amman shows that the per capita consumption rate of electricity in the summer season-July 2015-is highly variable between the administrative city sectors, as shown in Fig. 5. In this investigation, the spatial distribution pattern of per capita of domestic electricity consumption with the population density shows that the east and downtown parts of Amman have lower consumption values compared with the other residential neighborhoods in the west part of the city.

The statistical relationship between the dependent variable and the independent variables are given in Fig. 6. The figure reflects the relations between the consumption of

Table 4 Electrical losses by sector type (GW.h) [8]

\begin{tabular}{|c|c|c|c|c|}
\hline Years & 2014 & 2015 & 2016 & 2017 \\
\hline \multicolumn{5}{|l|}{ Generation } \\
\hline Generated energy & 17,863 & 18,516 & 18,924 & 18,690 \\
\hline Sent out energy & 17,231 & 17,945 & 18,415 & 18,191 \\
\hline Power station auxiliary consumption (\%) & 3.54 & 3.08 & 2.69 & 2.67 \\
\hline \multicolumn{5}{|l|}{ Transmission } \\
\hline Purchased energy & 17,691 & 18,541 & 18,764 & 19,287 \\
\hline Sold energy & 17,370 & 18,213 & 18,447 & 18,963 \\
\hline Losses (\%) & 1.81 & 1.77 & 1.69 & 1.68 \\
\hline \multicolumn{5}{|l|}{ Distribution } \\
\hline Purchased energy & 16,305 & 17,282 & 17,663 & 18,320 \\
\hline Sold energy & 14,057 & 14,856 & 15,385 & 16,112 \\
\hline Losses (\%) & 13.79 & 14.04 & 12.90 & 12.05 \\
\hline \multicolumn{5}{|l|}{ Total energy losses in electricity sector } \\
\hline Sent out energy and imported energy & 17,666 & 18,548 & 18,749 & 19,281 \\
\hline Consumed and exported energy & 15,121 & 15,787 & 16,168 & 16,755 \\
\hline Losses (\%) & 14.41 & 14.89 & 13.77 & 13.1 \\
\hline
\end{tabular}



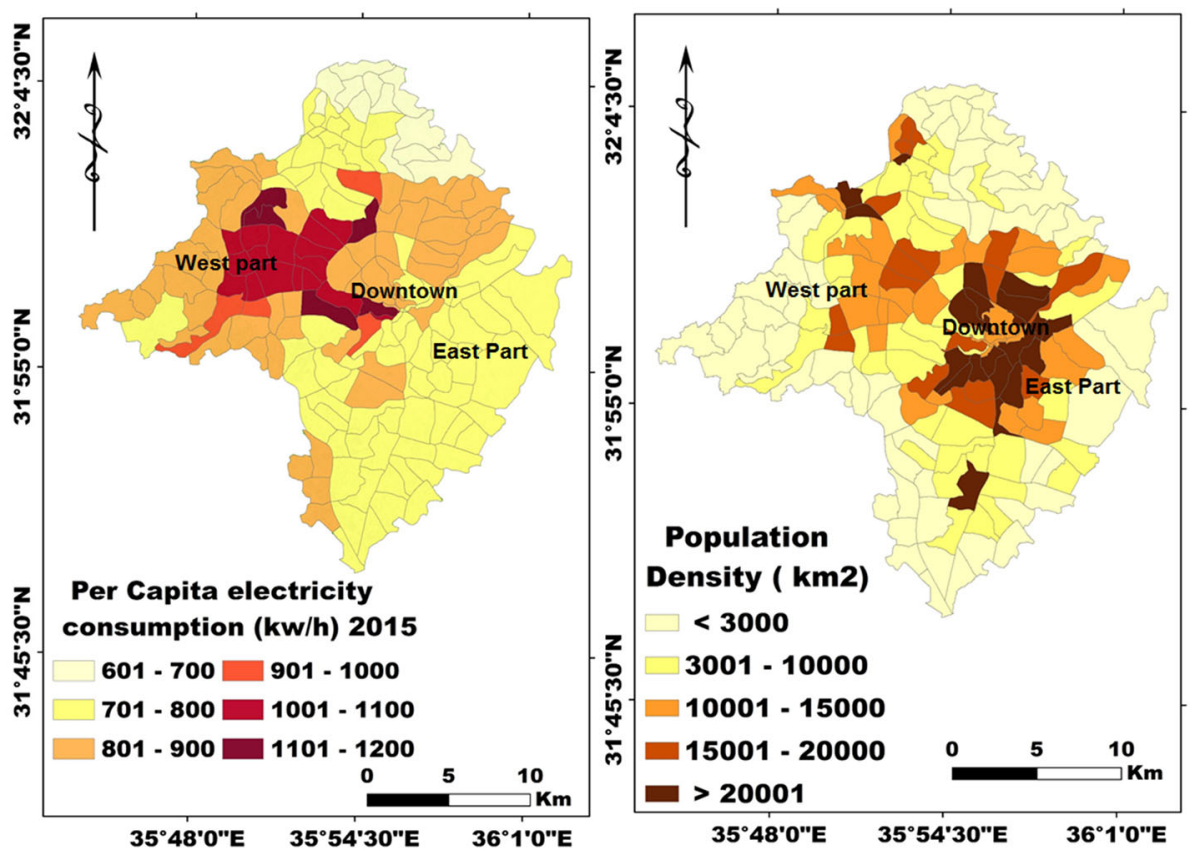

Fig. 5 a Pattern of per capita of domestic electricity consumption. $\mathbf{b}$ Pattern of population density in Amman

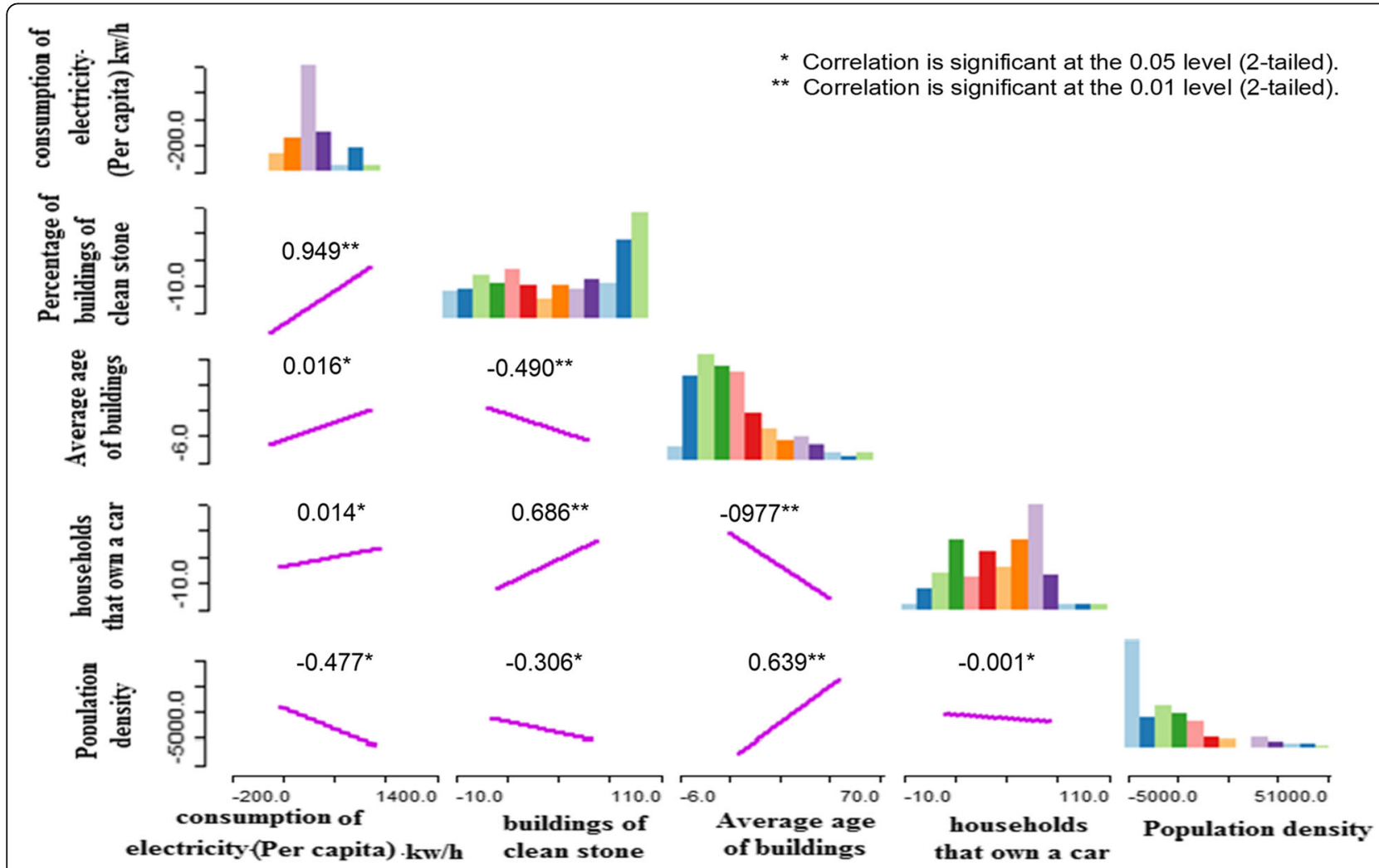

Fig. $\mathbf{6}$ Correlation between per capita electricity consumption and socioeconomic factors by scatter plot matrix 
electric energy and some of the socio-economic factors. Comparing the per capita consumption of electricity as the main economic factors with other demographic factors show that there is a positive relationship between the economic income level and the amount of consumed energy.

More specifically, a positive relationship was observed between the dependent factor from one side and the following independent factors from the other side (e.g., population density, a percentage of households owning a car, an average age of the building, type and material of building of clean stone). These results are confirmed by both the statistical analysis (Geoda software) [43] and the GIS spatial analysis test. As GIS can be used to display results as spatial maps to better communicate integrating it with building stock energy analysis and LCA due to its series of benefits. Given that the use of spatially explicit data contributes to the refinement and enrichment of the building inventory, making it possible to explicitly consider spatial constraints, e.g., linked to resource supply, building material, and any specific features, current and future infrastructures or networks, the suitability of renewable energy installations [44].

One of the interesting results is the positive effect of the building material types, where the stone building material proved a positive relationship with a significant statistical significance of 0.94 which is considered an indicator of economic prosperity. Noting that other researches results confirm the importance of the energy retrofitting of residential buildings in large functional urban areas. The LCA indicates that the selection of proper construction system materials and thermal insulation materials is important to the environmental performance of building retrofits, and these selections can lead to $\mathrm{CO} 2$ emission differences of up 16\% in the city [45]. While in Amman City, Shawarbeh mentioned that the residential and buildings of the city sending around $64 \%$ of the air pollution (including the CO2) [46].

The other factors represent positive relationships with lower significant values, except for the population density, which shows a negative correlation. This relationship means that the more densely populated areas, the lesser per capita consumption of electricity. These results show clear indicators on linking between socio-economic characteristics with energy consumption level in Amman City.

Considering energy consumption in Amman City, the analysis reflects the influence of several factors that should be taken into account in the energy sustainability strategies. The energy consumption is influenced by the characteristics of household including the building size, household income, total cost of energy, and building design, where the majority of buildings that were established in the new neighborhoods are distant from each other, this makes them affected by temperature in summer and winter compared to areas where the density of buildings are high. The results of the analysis show that areas with high-density buildings consume less energy, due to high population making the marginal cost per capita energy consumption lower compared to modern areas where the average of household size is small and the consumption per capita is higher, such result could be attributed to the low level of income of the heavily populated families with a large number of family members occupying individual rooms, consequently the rate of energy consumption will be divided on a large number of individuals.

Other important factors are the building's average age, design, and whether the buildings are following the latest standards codes (Methods of thermal insulation) for energy conservation. Buildings with diverse styles that are wide apart from each other are characterized by high-energy consumption pattern compared to the style of condensed buildings (e.g., the west part of Amman compared to the east and downtown parts). These findings are appearing clearly in Amman City as shown in Fig. 4, where the building style is dense and the population density is concentrated in the downtown region, this adverse relation is shown in the low consumption values in the city center compared to other parts. This result was confirmed by other studies which state that the low populated areas and distant buildings are featuring high-consumption rate pattern [47]. In addition to the above-mentioned factors, other factors may affect the energy consumptions such as the morphology of the city, location of the house and cultural behavior of the population [3].

According to the equation of income and expenditure issue, there is a self-evident that the proportion of expenditure and consumption linked to the rate of income, but the size of the association relationship and its proportion vary from one person to another or from one society to another. Regarding the factors of household characteristics and size as socio-economic variables, the cultural and social background plays an important role and are reflected on consumptions behavior of the individual and society as suggested by Reshmi study (2015) [47].

Figure 7 represents the spatial distribution of an average number of family members in Amman City for 2015-2016 [41]. It is obvious that there is a high rate of energy consumption in city neighborhoods that have a household size of up to almost 3.5 persons. On the other hand, the average household size is about (5.5) persons in the east and downtown side. The analysis shows that there is an obvious correlation between the size of the household and the amount of energy consumption in Amman City. In general, the studies show that the 


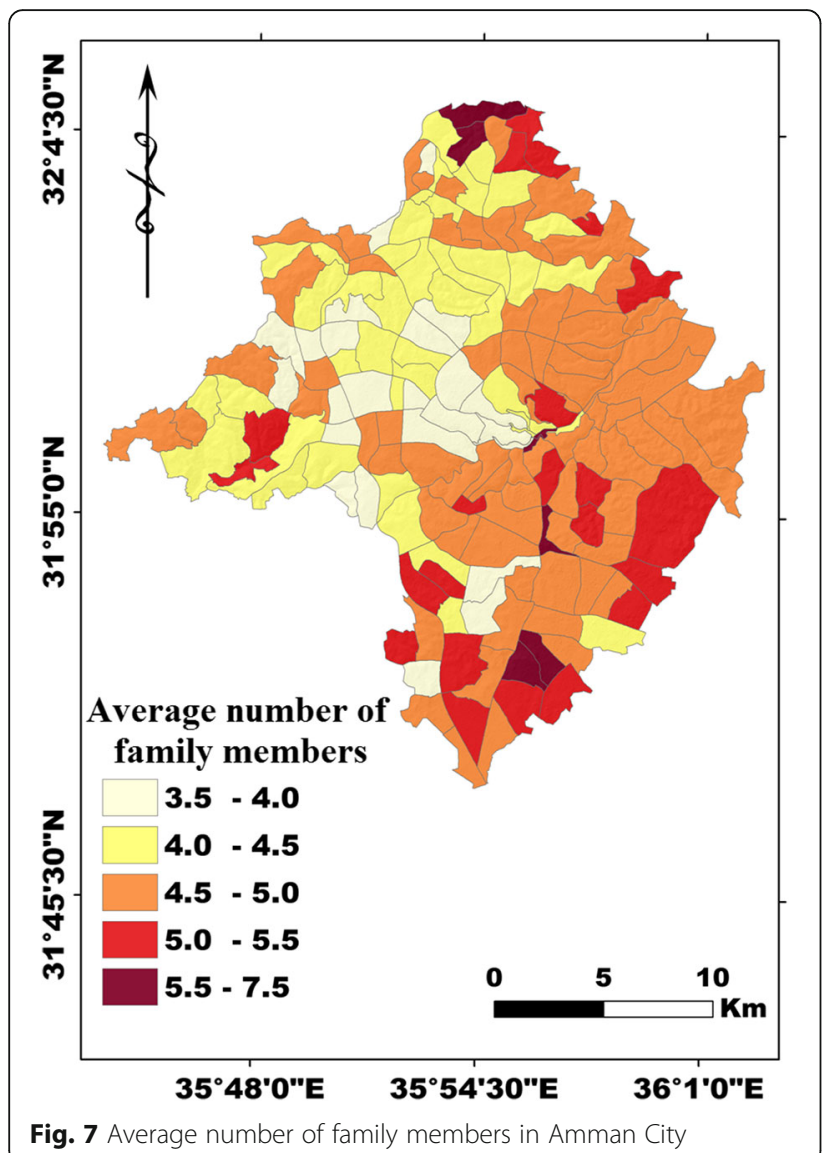

household member's number affects the average consumption rate and can be considered as a sign that higher-income households are the same who have a small household number. However, in the city of Amman, the result of the spatial analysis shows the same indication, in which the areas where there is low size for the family members, there was high per capita electricity consumption rate, and this in line with Moran's I findings.

Finally, it can be stated that the quantitative analysis of the socio-economic factors to the electricity consumption rate showed that the distribution pattern of energy consumptions can be attributed to many reasons including social behavior, economic conditions, and the pattern of energy consumption. This result is comparable to the findings of Urban "NEXUS" Approach, which stated that the economic conditions affect consumer and social behavior of the individual and vice versa, but they are not limited to economic and social factors.

\section{Conclusions}

Jordan imports about $97 \%$ of his need for power at a cost equivalent to $20 \%$ of the country's GDP. The volume of output losses during the distribution phase for 2015 is about $14.6 \%$ of total electricity consumption in Jordan. It distributed on three aspects is the generation, transmission, and distribution losses. Demand for energy in winter is about $17 \%$ in all sectors within the Amman City and the demand for the domestic sector is over $40 \%$ compared with the rest of the seasons. The low population density areas and buildings record higher consumption pattern, and the buildings are spaced in the city of Amman where high population density areas are concentrated in downtown and lower limbs, where the consumption values in the center of the city were lower than the other parts of the city. Building and construction sector is responsible for much of the energy used in urban environments and in many areas, this sector also contributes significantly to the impact effect on the local climate, for his role in the electric energy guzzling and generated mostly from the burning of fossil fuels. Investigation the spatial distribution of the consumption rate with the population density shows that the east and downtown parts of Amman having lower consumption values compared with the other residential neighborhoods in the west part of the city. Based on GIS analysis and (Geo Da) techniques as followed in LCA assist in communicating information with stakeholders (i.e., environmental organizations, communities, interested and affected parties, and authorities). The integration of GIS in LCA tool is capable to localize impact sources to organize spatial data especially at large scale; develop spatial inventory models and visualize results for stakeholders [15].

A positive relationship observed between the dependent factor (domestic energy consumption) and the factors of population density, percentage of households owning a car, the average age of the building, and type of building material. The high positive effect of the stone building material proved a positive relationship with a significant statistical significance, where the other factors represent low positive relationships, while the population density gave negative correlation. This relationship means that the more densely populated areas, show less the per capita consumption of electricity, and reflect clear indicators on linking between socio-economic characteristics with energy consumption level in Amman City.

\section{Abbreviations \\ DOS: Jordanian Department of Statistics; EDCO: Electricity Distribution Company; GIS: Geographic Information System; GW/h: Gigawatt hours; ICLEI: International Council for Local Environmental Initiatives; IDECO: Irbid District Electricity Company; JEPCO: Jordan Electricity Power Company; LCA: Life-Cycle Asessment; TTOE: Thousand ton oil equivalent; TW/ h: Terawatt-hour (TW/h) per hour}

\section{Acknowledgements}

The authors are grateful to the Jordanian Electric Power Co JEPCO for their cooperation in this study by data availability, and the authors are grateful to the two reviewers and the editorial team for their useful comments that have improved the paper.

\section{Funding}

The study was funded by the authors, under the umbrella of the Department of Geography at the Universities of Jordan and Birzeit. 


\section{Availability of data and materials}

Data and additional materials are available on request.

\section{Authors' contributions}

All sections of the study including concepts, designs, fieldwork were done by RND-M. Supervision, restructuring, proofreading, and conducting the revision of the study approach were done by ZM. All the authors contributed to the conclusions, the abstract, and the outlook of the study. All authors read and approved the final manuscript.

\section{Authors' information}

Rami is (Ph.D.) candidate in geography, his domain focus on urban environmental management, he has a good working expertise in assessing the sustainability of ecosystem services in urban as well as in green areas; such services like air quality, noise pollution and socio-economic era related to an urban environment. Rami has a former interest in morphometric studies and flood management in the semi-arid and urban areas, in addition to advanced experience in Remote Sensing (RS), Geographic Information System (GIS), Cartography and data visualization. Rami worked on several types of research using spatial statistical analysis to find out the relationship between human and nature characteristics in Jordan and Palestine. He has membership in Arab Council for the Social Sciences and Jordan Green Building Council (JGBC).Also, he participated in many scientific conferences and has many published papers. ZM is a professor in the field of applied environmental sciences in the Geography department at the University of Jordan. He is a specialist in GIS spatial modeling and Remote Sensing applications in environmental science in the Dryland regions and urban ecosystems. The interest in the urban system lay mainly in the relationship between urban expansion and population services and the effector urbanization growth on the floods characteristics in the cities. He has acquired extensive expertise in various aspects of applied environmental science, his research focuses on applied remote sensing and spatial analysis in and land use changes, monitoring of land degradation, climate change, and watershed management. He has many publications in international Journals and conferences and participates in different workshops and projects in the related fields.

\section{Competing interests}

The authors declare that they have no competing interests.

\section{Publisher's Note}

Springer Nature remains neutral with regard to jurisdictional claims in published maps and institutional affiliations.

\section{Received: 3 September 2018 Accepted: 17 April 2019}

Published online: 09 May 2019

\section{References}

1. Al-Shami K (2007) Environmental pollution in cities. Amman-Jordan, Dar AlQuds for Publishing and Distribution.

2. Becqué R, Mackres E, Layke J, Aden N, Liu S, Managan K et al (2016) Accelerating building efficiency: eight actions for urban leaders. World Resources Institute, Washington, DC.

3. Energy efficiency of buildings: a new challenge for urban models. Applied Urban Modelling: Assessing Pathways Towards Energy Efficient and ClimateWise Regions, Cambridge: British Academy, Forthcoming. Available at SSRN: https://ssrn.com/abstract=2364614.

4. Hamza A (2016) City morphology. University of Babylon, Iraq.

5. Kennedy, C., . Cuddihy, J.. Engel-Yan, J. (2007). "The changing metabolism of cities." J Ind Ecol:11:43-59.

6. DESA, U. Population Division (2015) World population prospects: the 2015 revision, key findings and advance tables. United Nations, New York, p 53.

7. Agency IE (2015) Energy technology perspective mobilizing innovation to accelerate climate action. Technology roadmap: energy-efficient buildings: heating and cooling equipment. International Energy Agency, Paris, p 418.

8. J. E. C, Jordan Electricity Company. (2017). Unpublished statistical data for electricity consumption in 2016-2015 Amman-Jordan.

9. Vogt, C., Schlenk, J. C., Horne, C., \& Gügel, C. (2014). Operationalizing the urban NEXUS towards resource-efficient and integrated cities and metropolitan regions: Case studies. Deutsche Gesellschaft für Internationale Zusammenarbeit (GIZ) GmbH., from http://www2.giz.de/wbf/ 4tDx9kw63gma/UrbanNEXUS_Publication_ICLEI-GIZ_2014_kl.pdf.
10. Hettiarachchi, H. a. M. Z (2018) The Nexus approach in environmental resources management. Germany, Iran, p 36.

11. Statistics, D. T. D. o. (2017). Jordan statistical yearbook: electricity tables 2017. a. Consumed electricity by usage. Jordan National Electric Power Company.

12. Vergragt $P$, Schroder P, Brown H, Dendler L, Dallessio T, Gorenflo N, Matus K, Quist J, Rupprecht C, Tukker A, Waheed A, Wennersten R, Xiong Y, Zhang L (2018) Systems of Sustainable Consumption and Production, KAN knowledge-action networks - working groups-sustainable consumption and production in cities. USA, Tellus Institute.

13. Sharma P (2009) GIS mapping analysis of energy consumption patterns in Nepal. Geogr J Nepal 7:41-52.

14. Geyer R, Stoms DM, Lindner JP, Davis FW, Wittstock B (2010) Coupling GIS and LCA for biodiversity assessments of land use: Part 1: Inventory modeling.

15. Mastrucci A, Popovici E, Marvuglia A, De Sousa L, Benetto E, Leopold U (2015) GIS-based Life Cycle Assessment of urban building stocks retrofittinga bottom-up framework applied to Luxembourg. In: Envirolnfo and ICT for Sustainability 2015. Atlantis Press Available from: https://www.researchgate. net/publication/299966981_GISbased_Life_Cycle_Assessment_of_urban_. building_stocks_retrofitting-_a_bottom-up_framework_applied_to_ Luxembourg. Accessed 11 Jan 2019.

16. Zhu J, Zhang Q, Tong Z (2015) Impact analysis of lakefront land use changes on lake area in Wuhan, China. Water, 7(9):4869-4886. http://www. mdpi.com/2073-4441/7/9/4869/htm. Accessed 9 Jan 2018.

17. ICLEI - Local Governments for Sustainability (2004) Sustainable urban energy planning a handbook for cities and towns in developing countries. UNON, Publishing Services Section, Nairobi ISO 14001:2004-certified.

18. Commission, E. M. R (2016) General Electric Statistics. T. E. S. C. t. J. Consumption. Electricity Sector, Jordan From: http://www.emrc.gov.jo/index. php/en/statistics.

19. N.E.P.C, (2016). National Electric Power Company Annual Report for the year of 2016.

20. N.E.P.C, (2017). National Electric Power Company: annual report for the year of 2017.

21. E.M.R.C, (2016). Energy and minerals regulatory commission annual report 2016.

22. M.E.M.R, T. M. O. E. a. M. R. (2014). Energy status in Jordan, the 10th Arab energy conference. Abu Dhabi City - United Arab Emirates.

23. Statistics, D.-J. D. o (2016) Jordan, figures. Jordan, figures, Jordanian Department of Statistics, Amman.

24. Obaidat, M. T. (2016). "Public transport culture in Jordan." From: http://www. Itrc.gov.jo/?q=ar/node/221702. Retrieved 8/22/2018.

25. Ruelle C, Teller J (2016) Guided group purchases of energy renovation services and works in deprived urban neighbourhoods. Energ Effic 9(4): 861-874.

26. Kumar, A. (2016). The state of European cities 2016: cities leading the way to a better future. http://ec.europa.eu/regional_policy/sources/policy/ themes/cities-report/state_eu_cities2016_en.pdf.

27. García-Pérez S, Sierra-Pérez J, Boschmonart-Rives J, Morales GL, Cálix AR (2017) A characterisation and evaluation of urban areas from an energy efficiency approach, using geographic information systems in combination with life cycle assessment methodology. Int I Sustain Dev Plan 12(2):294-303.

28. Gram-Hanssen K (2013) Efficient technologies or user behaviour, which is the more important when reducing households' energy consumption? Energ Effic 6(3):447-457.

29. Standardization, I. O. f. (2018). "Energy management systems -- requirements with guidance for use, ISO50001." From: https://www.iso.org/standard/ 69426.html.

30. Tallini A, Cedola L (2016) Evaluation methodology for energy efficiency measures in industry and service sector. Energy Procedia 101:542-549.

31. Gebber F, Al-Hunaiti I (2016) Energy efficiency and renewable energy forum challenges and opportunities of Jordanian industry, president of the association of small and medium enterprises. $4 \mathrm{~m}$, Amman.

32. Rifkin J (2011) The third industrial revolution roadmap next economy for the metropolitan region of Rotterdam and the Hague. Roadmap Next economy, New York.

33. Banerjee R (2015) Importance of Energy Conservation Reshmi Banerjee. Int J Innov Res Adv Eng 2(4):186-190 http://www.jijrae.com/volumes/Nol2/iss4/ 34.APAE10052.pdf. ISSN: 23492163. 
34. Al-Ghandoor A, Al-Hinti I, Akash B, Abu-Nada E (2008) Analysis of energy and exergy use in the Jordanian urban residential sector. Int J Exergy 5(4): 413-428.

35. Al-Majali A, Alrfua A (2018) Estimate demand for electricity consumption of the household sector in Jordan using VECM model for the period (1980 2015). Jordanian J Econ Sci 5(1):19.

36. Österbring M, Mata É, Johnsson F, Wallbaum H (2014) A methodology for spatial modelling of energy and resource use of buildings in urbanized areas. In: World Sustainable Building Conference WSB14 Barcelona.

37. FAIR, H (2016) Industrial Scars The Hidden Costs of Consumption. Audubon Magazine. United Kingdom, Papadakis, p 204.

38. Agency, E. P. (2013). "A Students Guide to Global Climate Change." From: https://mcnie.fireflymkt.com/userfiles/PDFS/ Global\%20Climate\%20Change.pdf.

39. Lee $\mathrm{S}$, Lee B (2014) The influence of urban form on GHG emissions in the US household sector. Energy Policy 68:534-549 https://pdfs.semanticscholar. org/5a1c/3850019b5995791b22909e57e039f49c6d6e.pdf.

40. Adrian K, Alan EBW (2004) Residential Energy Use in Sydney, the Blue Mountains and the Illawarra-Results from the 2003 Household Survey. (IPART) Independent Pricing and Regulatory Tribunal of New South Wales 102, Sydney.

41. Department, D. O. S. J. S. (2015). Selected indicators, 2013-2016 Amman, Jordanian Statistics Department. From: http://dosweb.dos.gov.jo/DataBank/ JordanInFigures/JORINFIGDetails2017.pdf.

42. Al-Assaf M (2017) Interview- solid waste management. M. Rami. Amman.

43. Anselin, Luc (2018) GeoDa an introduction to spatial data analysis, Exploratory Data Analysis (2) Multivariate Exploration. https://geodacenter. github.io/workbook/2b_eda_multi/lab2b.html\#fn1.

44. Mastrucci A, Marvuglia A, Leopold U, Benetto E (2017) Life cycle assessment of building stocks from urban to transnational scales: a review. Renew Sust Energ Rev 74:316-332.

45. García-Pérez S, Sierra-Pérez J, Boschmonart-Rives J (2018) Environmental assessment at the urban level combining LCA-GIS methodologies: a case study of energy retrofits in the Barcelona metropolitan area. Build Environ 134:191-204.

46. Shawarbeh, Yousef (2014) Global covenant cities. greenhouse gas emissions https://www.epa.gov/ghgemissions/global-greenhouse-gas-emissions-data, https://www.globalcovenantofmayors.org/cities/?s=\&page=0\&is_v=1.

47. Ewing $R$, Rong $F$ (2008) The impact of urban form on US residential energy use. Hous Policy Debate 19(1):1-30.

Ready to submit your research? Choose BMC and benefit from:

- fast, convenient online submission

- thorough peer review by experienced researchers in your field

- rapid publication on acceptance

- support for research data, including large and complex data types

- gold Open Access which fosters wider collaboration and increased citations

- maximum visibility for your research: over $100 \mathrm{M}$ website views per year

At BMC, research is always in progress.

Learn more biomedcentral.com/submissions 